\title{
Advanced FeCrAl ODS steels for high-temperature structural applications in energy generation systems ${ }^{(*)}$
}

\author{
G. Pimentel*, C. Capdevila*, M. J. Bartolomé*, J. Chao*, M. Serrano**, A. García-Junceda**, M. Campos***, \\ J. M. Torralba*** and J. Aldazábal****
}

\begin{abstract}
Technologies and means for developing biomass plant with higher energy conversion efficiencies are essential in order to implement the commitment to renewable biomass energy generation. Advanced, indirect Combined Cycle Gas Turbine (CCGT) systems offer overall biomass energy conversion efficiencies of $45 \%$ and above, compared with the $35 \%$ efficiency of conventional biomass steam plant. However to attain this efficiency in CCGT operation it will be necessary to develop a heat exchanger capable of gas operating temperatures and pressures of around $1100^{\circ} \mathrm{C}$ and 15-30 bar, respectively, for entry heating the gas turbine working fluid. ODS ferritic steels is the kind of advance material to deal with this challenge, however work to optimize the coarse grain microstructure to improve creep hoop strength needs to be done. In this sense, this paper reports the recrystallisation behaviour of PM 2000 oxide dispersion strengthened ferritic alloy which was cold deformed after hot-rolling and extrusion. The results can be interpreted if it is assumed that anything which makes the microstructure heterogeneous, stimulates recrystallisation. In this sense, larger strain gradients lead to more refined and more isotropic grain structures. The combination of these results with finite element modeling are used to interpret the role of residual shear stresses on the development of recrystallized grain structure.
\end{abstract}

\section{Aceros ODS FeCrAl avanzados para aplicaciones estructurales de alta temperatura en sistemas de generación de energía}

Resumen

Palabras clave

\begin{abstract}
Las tecnologías y medios para desarrollar plantas de biomasa con alta eficiencia en la conversión de energía son esenciales para asentar la biomasa como una fuente de energía renovable. Los sistemas de turbinas de gas de ciclo combinado (CCGT) permiten elevar la eficiencia de las plantas de biomasa del $35 \%$ actual al $45 \%$. Sin embargo, para conseguir estos niveles de eficiencia en la conversión de energía, el intercambiador de calor de la caldera debe trabajar en condiciones extremas de temperatura (por encima de $1100^{\circ} \mathrm{C}$ ) y presión (en torno a 15-30 bar). Los aceros ODS ferríticos son la clase de material avanzado específicamente diseñado para trabajar en ambientes altamente corrosivos y a temperaturas elevadas. Pero para mejorar la resistencia a la fluencia a altas temperaturas en dirección circunferencial, la microestructura generada en el proceso de recristalización ha de ser diferente a la microestructura axi-simétrica altamente anisótropa que tiene este tipo de aceros por defecto. En este sentido, este trabajo detalla los resultados obtenidos en la aleación reforzada por dispersión de óxidos PM 2000 que ha sido fabricada por técnicas pulvimetalúrgicas, consolidada por extrusión y conformada por laminación en caliente y en frio. De los resultados obtenidos puede concluirse que una microestructura heterogénea estimula su recristalización, de forma que grandes gradientes de deformación generan microestructuras más finas e isótropas. La comparación de estos resultados con simulaciones por elementos finitos ha permitido dilucidar el papel que tienen las tensiones residuales subyacentes en la microestructura en la generación de la microestructura recristalizada.
\end{abstract}

Aleación ODS; Acero inoxidable ferrítico; Óxidos; Biomasa; Recristalización.

(•) Trabajo recibido el día 22 de noviembre de 2011 y aceptado en su forma final el día 22 de febrero de 2012.

* Materalia Research Group, Department of Physical Metallurgy, Centro Nacional de Investigaciones Metalúrgicas (CENIM-CSIC), Avda. Gregorio del Amo, 8. E-28040 Madrid, Spain.

** División de Materiales Estructurales, Centro de Investigaciones Energéticas, Mediambientales y Tecnológicas (CIEMAT), Avda de la Complutense 40. 28040 Madrid, Spain.

*** Universidad Carlos III de Madrid (UC3M), Av. Universidad 30, 28911 Leganés, Madrid, Spain

**** Centro de Estudios e Investigaciones Técnicas de Guipúzcoa (CEIT - Tecnun), Universidad de Navarra, Paseo Manuel de Lardizábal 15, 20018 San Sebastián, Spain. 


\section{INTRODUCTION}

There are several potential advantages in employing ferritic Fe-Cr-Al alloys in high temperature applications: in addition to the lower raw material cost and generally superior oxidation resistance, the alloys have a higher melting point, lower density and lower coefficient of thermal expansion than the current nickel or cobalt base alloys. The original interest in $\mathrm{Fe}-\mathrm{Cr}$ - $\mathrm{Al}$ alloys was for high temperature power plant applications. However, the mechanical strengths of the alloys in the cast and wrought condition at temperatures in excess of about $600^{\circ} \mathrm{C}$ were too low for them to be considered for critical structural applications. Dispersion strengthening with stable oxide particles is an ideal method for improving high temperature strength without sacrificing the excellent surface stability of the matrix alloy.

The global requirement for reducing $\mathrm{CO}_{2}$ emissions from fossil power plant is driving the design and construction of plant with higher efficiencies, along with co-firing and $\mathrm{CO}_{2}$ capture technologies. Recently, there is a commitment in Europe to renewable energy; biomass is likely to make a significant contribution to this type of power generation $^{[1]}$. This does not require radically new technologies when compared with alternative sources of renewable energy. However, the thermodynamic efficiency of the process is dependent on the maximum temperature which can be attained in the operating cycle. Gains in overall cycle efficiency generally involve increasing the maximum operating temperature of the power plant. Such improvements have and will continue to be enabled by the development of materials with increasingly high temperature capabilities. Technologies for developing biomass plant towards greater efficiencies are therefore vital. For example, it is planned to construct heat exchanger capable of gas operating temperatures and pressures of around $1100^{\circ} \mathrm{C}$ and $15-30$ bar $^{[2]}$. This in turn requires metal tubing which can survive at temperatures up to $1150^{\circ} \mathrm{C}$.

Oxide Dispersion-Strengthened (ODS) FeCrAl alloys have excellent potential for use in next-generation high-temperature applications where superior creep strength and oxidation resistance compared to current alloys is required. Possible applications include tubing for high-temperature heat exchangers and sheet for burners and combustion chambers. Among the three challenges that currently inhibit the use of these alloys, i.e. relatively high processing costs, improve actual joint techniques due to low creep strength at high temperatures, and generate recrystallization microstructures with large grains custom oriented with respect to the principal hoop creep stress; this paper reviews the results achieved to address the latter issue by a consortium formed by División de Materiales Estructurales, Centro de Investigaciones Energéticas, Mediambientales y Tecnológicas (CIEMAT), Centro de Estudios e Investigaciones Técnicas de Guipúzcoa (CEITTecnun), Universidad Carlos III de Madrid and Centro Nacional de Investigaciones Metalúrgicas (CENIM-CSIC).

\section{CHARACTERIZATION OF FINE GRAINED MICROSTRUCTURE}

The oxidation resistance and good creep performance of mechanically alloyed FeCrAl ODS alloys such as PM 2000 and MA956, makes them prime candidates for the proposed heat exchangers $\left.{ }^{[3 \text { and }} 4\right]$. As expected, the creep strength is influenced by grain size and shape ${ }^{[5]}$. The microstructure, however, following mechanical alloying and consolidation of the resulting powder (for example, by extrusion), consists of fine grains which have a width which is much less than a micrometer and which are colddeformed during the consolidation process ${ }^{[6}$ and 9$]$. The material in this state is hard and contains an enormous amount of stored energy ${ }^{[10}$ and 11$]$. However, recent studies ${ }^{[10}$ and 11$]$ concluded that the microstructure in the as-extruded and hot rolled condition of PM 2000 consists of fine $(\sim 0.5 \mu \mathrm{m})$ grains of ferrite (Fig. $1 \mathrm{a}$ ) and b)). The grains were slightly elongated in the extrusion and rolling direction and the microstructure exhibited no major rolling texture. This microstructure indicates that the rolling temperature is high enough for recrystallization to have occurred with possibly a little grain growth. Electron backscatter diffraction (EBSD) indicated that the high angle grain boundaries are well defined, which is also consistent with a recrystallized microstructure. Furthermore, texture analyses reveal a weak fiber texture, $\sim 1.4$ times random, with the $\langle 110\rangle$ direction parallel to the rolling direction, i.e. the (110) plane is perpendicular to the bar axis (Fig. $1 \mathrm{c})$ ). This texture is typical of body centered cubic materials deformed by either extrusion or rolling.

Klimiankou et al. ${ }^{[14}$ and 15$]$ have reported detailed studies with conventional TEM and energy filter TEM (EFTEM) measurements, and conclude that ODS particles with sizes ranging from $3 \mathrm{~nm}$ to $40 \mathrm{~nm}$ are homogeneously distributed in the sample. The ODS particles consist of $\mathrm{Y}_{3} \mathrm{Al}_{5} \mathrm{O}_{12}$ garnet (YAG) and $\mathrm{YAlO}_{3}$ perovskite (YAP) phases which were 
ADVANCED FeCrAI ODS STEELS FOR HIGH-TEMPERATURE STRUCTURAL APPLICATIONS IN ENERGY GENERATION SYSTEMS ACEROS ODS Fe Cr Al AVANZADOS PARA APLICACIONES ESTRUCTURALES DE ALTA TEMPERATURA EN SISTEMAS DE GENERACIÓN DE ENERGÍA

determined using HRTEM, XRD and EDX methods. Apart from the ODS particles, numerous large inclusions with complex compositions were found in the sample. The investigations showed the formation of large $\gamma-\mathrm{Al}_{2} \mathrm{O}_{3}$ inclusions as well as complex $\gamma-\mathrm{Al}_{2} \mathrm{O}_{3} / \mathrm{Y}$-Al-O impurities, which may additionally enclose smaller $\mathrm{Ti}(\mathrm{C}, \mathrm{N})$ particles. Formation of Ti containing ODS particles was not found. The main fraction of $\mathrm{Ti}$ inside the sample forms $\mathrm{Ti}(\mathrm{C}, \mathrm{N})$ or $\mathrm{TiN}$ inclusions which also may enclose small, ODS like Y-Al-O particles. Klimiankou et al concluded that the variety of particles analyzed is a hint of the complexity of chemical reactions, which occur during the production process of ODS alloy and leads to dissolution of former oxide particles and precipitation of new ones. Figure 2 shows the particles identified, as well as the raw data sorted as a frequency distribution showing the number of particles having sizes between certain values.

\section{GENERATION OF HIGHLY ANISOTROPIC MICROSTRUCTURES}

Only coarse recrystallized grains have adequate high temperature creep strength. Therefore, the as-extruded and hot-rolled material has to be recrystallized into a coarse-grained microstructure before using. However, the recrystallization behavior of iron-base ODS alloys is peculiar. They recrystallize into a grain structure which resembles that obtained by directional solidification, with coarse, columnar grains which have their longest axes along the extrusion direction. This results in tubes with anisotropic, very coarse grained, axially aligned microstructures which exhibit excellent axial creep properties. Furthermore, recrystallization usually does not occur until temperatures close to melting are reached $^{[16-18] \text {. }}$

Annealing at temperatures of the order of 0.9 of the melting-point $\left(1360^{\circ} \mathrm{C}\right.$ for $\left.3 \mathrm{~h}\right)$, and cooling in a switched off furnace yields a coarse grain structure with a grain size in the millimeter range. The grains are columnar and aligned along the extrusion direction (Fig. 3).

After this heat treatment, some aluminum-yttrium oxides were observed (Fig. 4 a)). The mean size of these particles was $\sim 60 \mathrm{~nm}$ (Fig. $4 \mathrm{c}$ )), which according to the results shown in figure 2 allow us to conclude that recrystallization heat treatment leads to coarsening of oxide particles. The composition of the particles (Fig. 4 b)) was estimated by energydispersive spectroscopy to be 43.4 at. $\% \mathrm{Al}, 3.3 \% \mathrm{Y}$
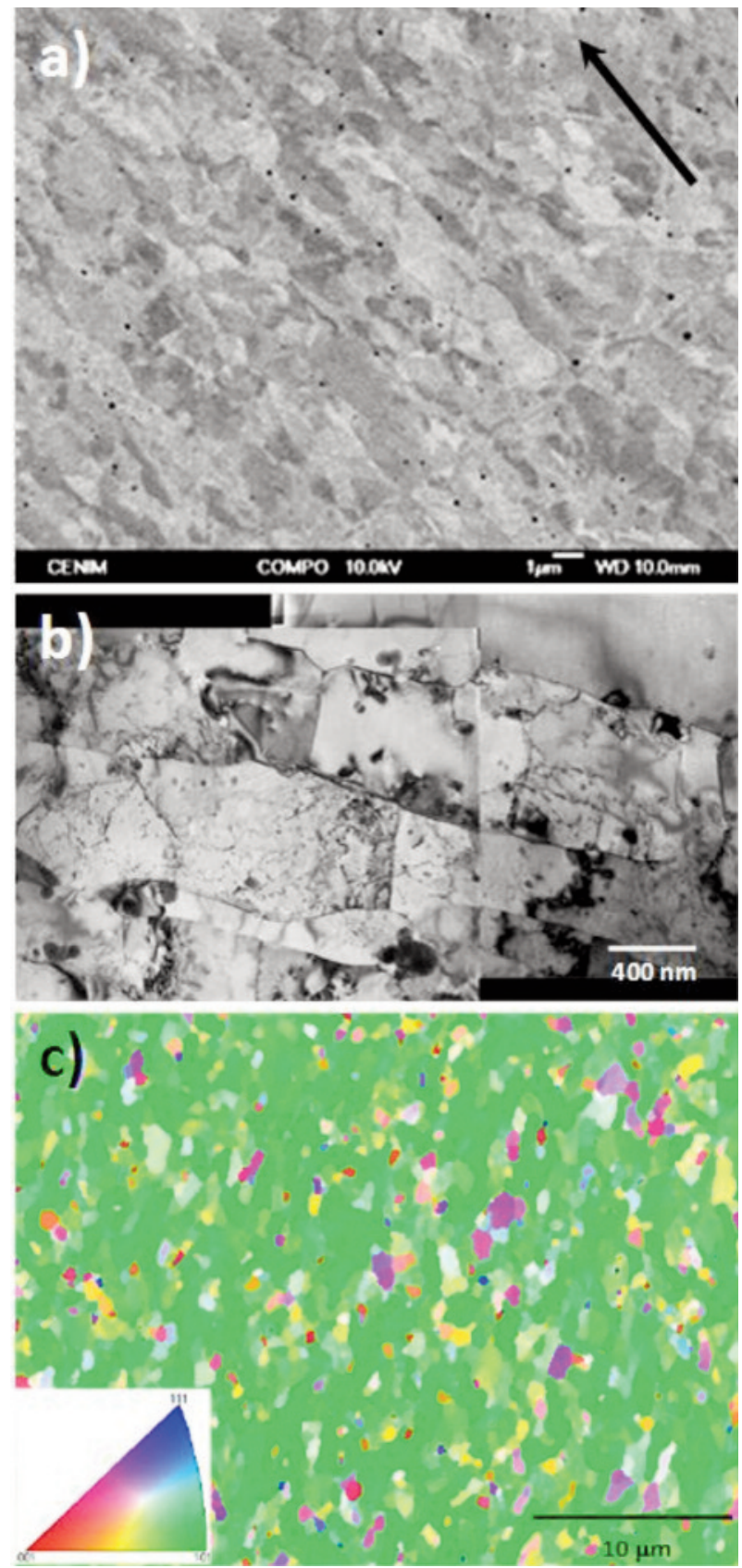

Figure 1. As-rolled microstructure of PM 2000: a) Electron backscattered image, b) TEM micrograph of longitudinal section, and c) IPF map for transverse section. Arrow indicates extrusion and hot rolling direction.

Figura 1. Microestructura de laminación de PM 2000: a) imagen SEM por electrones retrodispersados, b) micrografía TEM de la sección longitudinal, y c) mapa IPF de la sección transversal. La flecha indica la dirección de extrusión y laminación en caliente.

and $53.2 \%$ O which was not consistent with the original stoichiometry of the $\mathrm{Y}_{2} \mathrm{O}_{3}$ powder. This composition is also very different from that observed 
a)

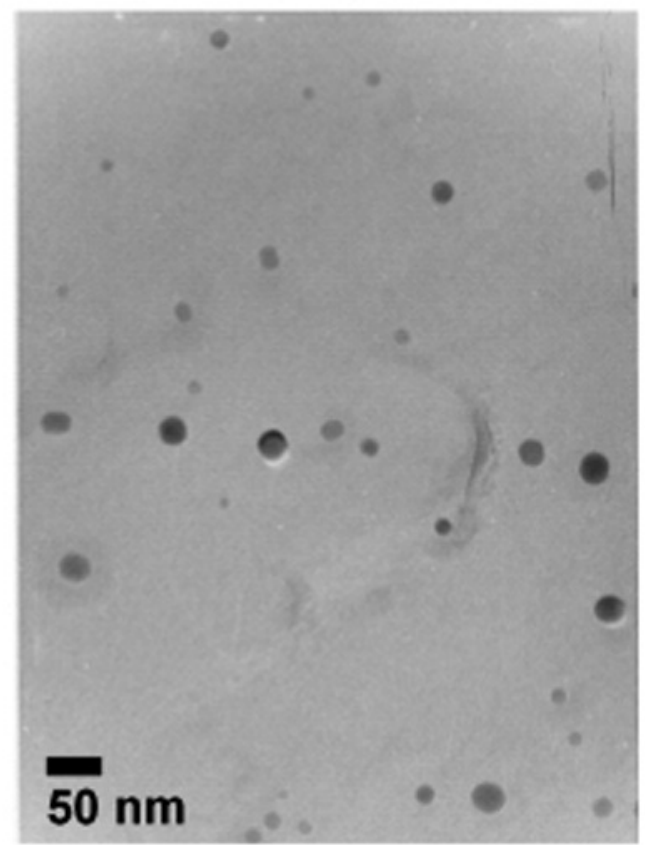

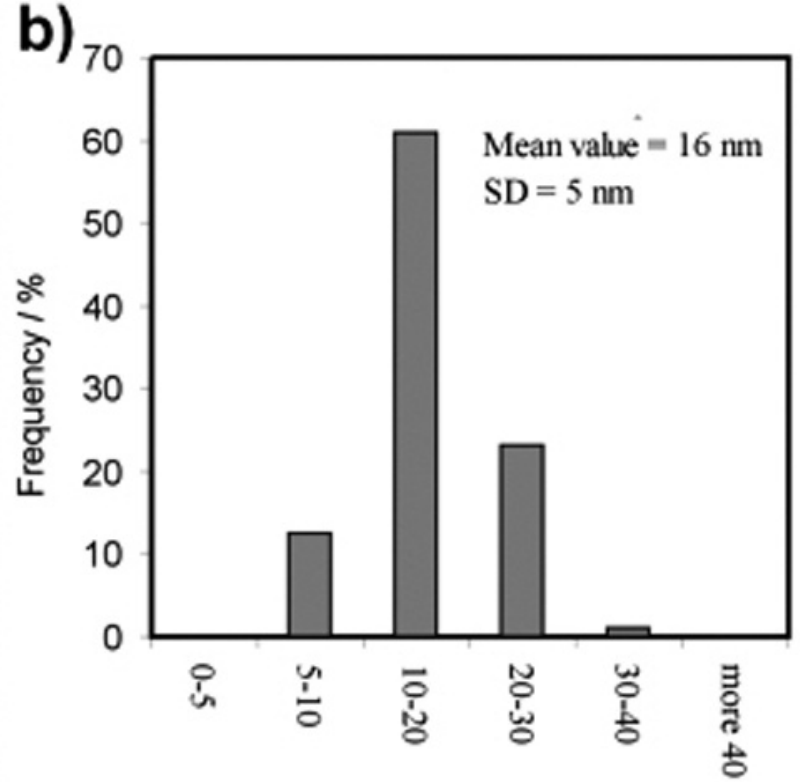

Particles diameter / nm

Figure 2. PM 2000 in as-received condition: a) Particle orientation, b) distribution sizes

Figura 2. Microestructura de PM 2000 en la condición de recepción: a) alineación de dispersoides, y b) distribución de tamaños.

by Klimiankou et al, who observe a composition close to $\mathrm{YAlO}_{3}{ }^{[14]}$.

The high aluminum content suggests that these oxides are not remnants of the original yttria powder and that the original yttria powder was dissolved into the solid solution during the mechanical alloying process and a new distribution of oxide particles formed during the extrusion or rolling processes. This high temperature annealing treatment was used prior to subsequent lower temperature ageing treatments to ensure a chemically homogeneous material. The reason why the growth of grains is anisotropic is two-fold. Firstly, because of the segregation of particles on the grain
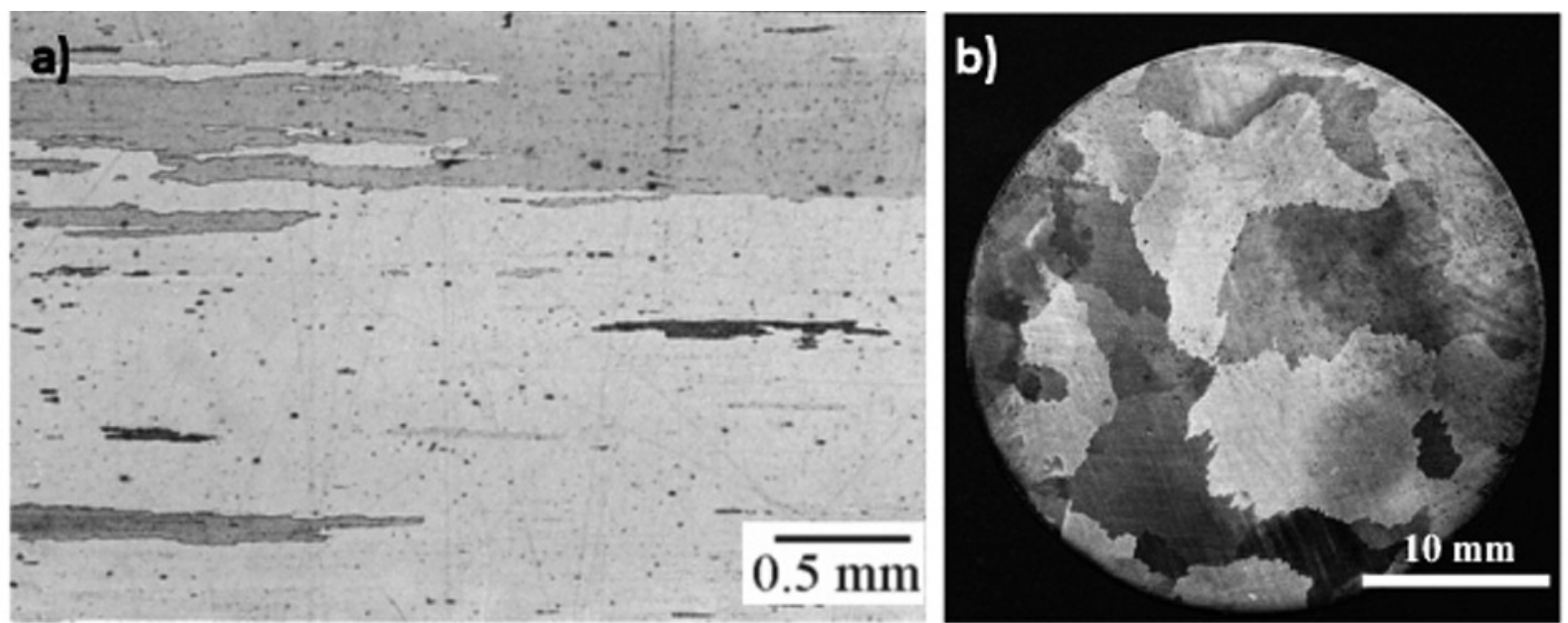

Figure 3. a) Longitudinal and b) cross-section of recrystallized microstructure of the bar after annealing at $1350{ }^{\circ} \mathrm{C}$ for $3 \mathrm{~h}$.

Figura 3. a) Sección longitudinal y b) transversal de una barra recristalizada después de un recocido a $1.350^{\circ} \mathrm{C}$ durante $3 \mathrm{~h}$. 
ADVANCED FeCrAI ODS STEELS FOR HIGH-TEMPERATURE STRUCTURAL APPLICATIONS IN ENERGY GENERATION SYSTEMS ACEROS ODS Fe Cr Al AVANZADOS PARA APLICACIONES ESTRUCTURALES DE ALTA TEMPERATURA EN SISTEMAS DE GENERACIÓN DE ENERGÍA

a)

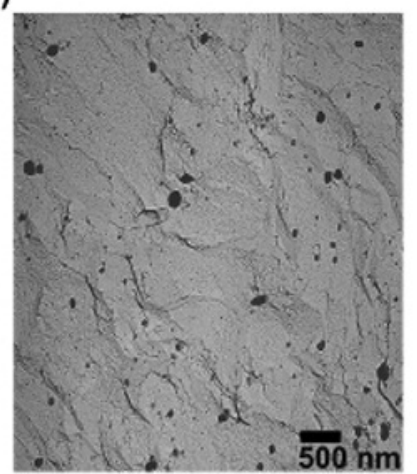

b)

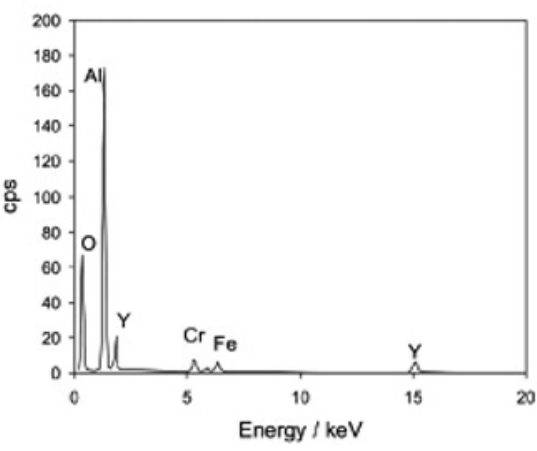

c)

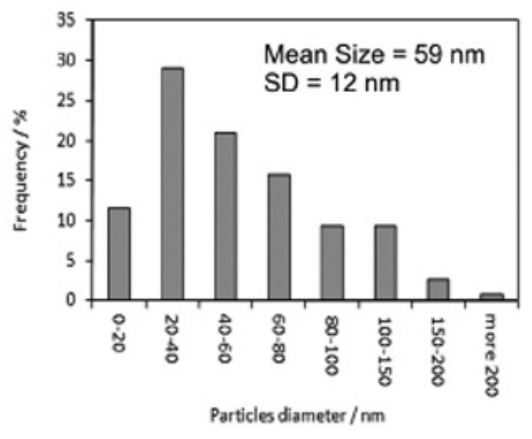

Figure 4. PM 2000 after isothermal heat treatment at $1350{ }^{\circ} \mathrm{C}$ for $3 \mathrm{~h}$ : a) Particle orientation, b) EDS spectra, and c) distribution sizes. SD stands for standard deviation.

Figura 4. Microestructura de PM 2000 después de un tratamiento isotérmico a $1.350^{\circ} \mathrm{C}$ durante $3 \mathrm{~h}$ : a) orientación de las partículas, b) espectro EDS, y c) distribución de tamaños. SD indica desviación estándar.

boundary of deformed grains (Fig. 5 a)), and secondly because of the strong alignment of the aluminum-yttrium oxide particles along the extrusion direction (Fig. 5 b)) that hinder boundary motion more effectively in the transverse direction $^{[19-21]}$.

As the grain growth process can be influenced by solute segregation, the grain boundaries were investigated for evidence of solute segregation (particularly yttrium, since there is a remote possibility that fine yttria or yttrium containing oxide particles that are located at a grain boundary may partially or fully dissolve). Several randomly chosen boundaries were selected and orientated parallel to the incident electron beam; microanalysis scans at intervals of $2.5 \mathrm{~nm}$ were then conducted across the boundary plane over a distance of $\sim 0.16 \mu \mathrm{m}$ on either side of the boundary, avoiding any particles. A concentration scan through a precipitate-free segment of the grain boundary (Fig. 6 a)) revealed no evidence of solute enrichment at the grain boundary. For comparison, a scan across a segment of grain boundary with an aluminum-yttrium oxide particle is shown in figure $6 \mathrm{~b}$ ).
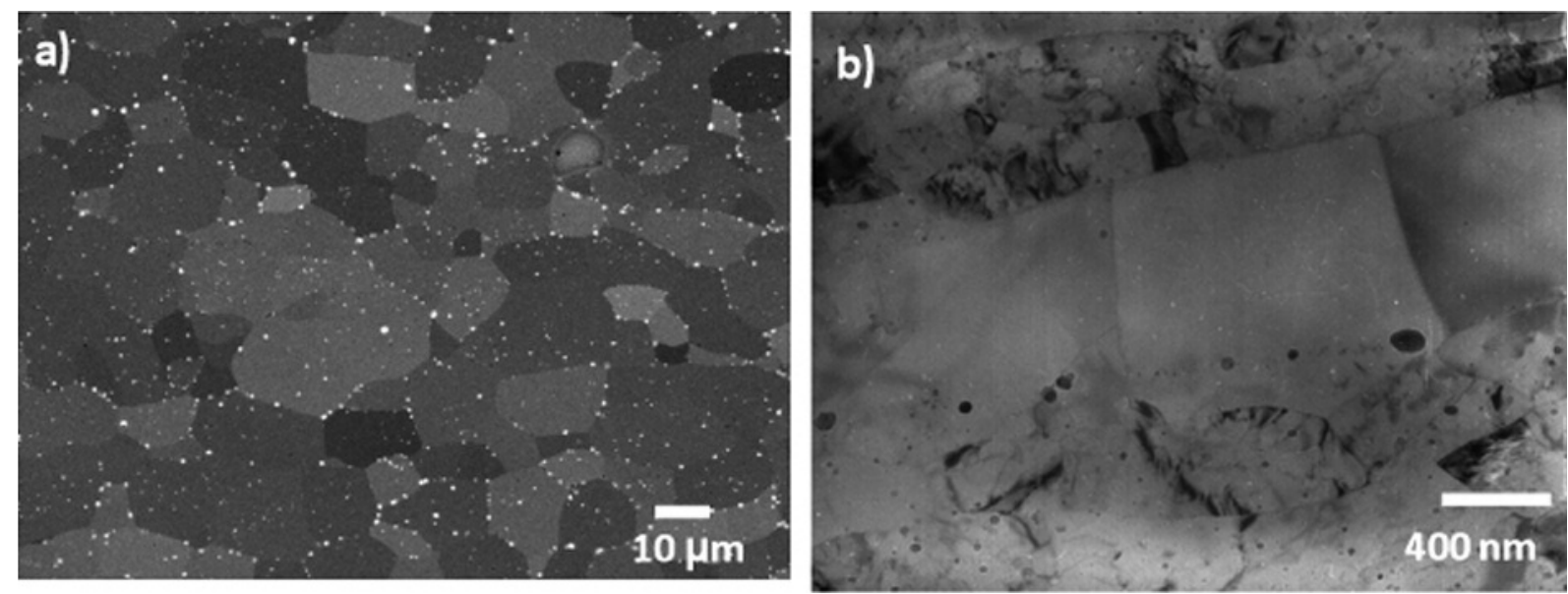

Figure 5. a) back-scattered SEM of grain boundary particles (in white) in transverse section, and b) TEM micrograph of longitudinal section.

Figura 5. a) microestructura SEM por electrones retrodispersados mostrando partículas (en blanco) segregadas en la frontera de grano, y b) micrografía TEM mostrando una sección longitudinal. 

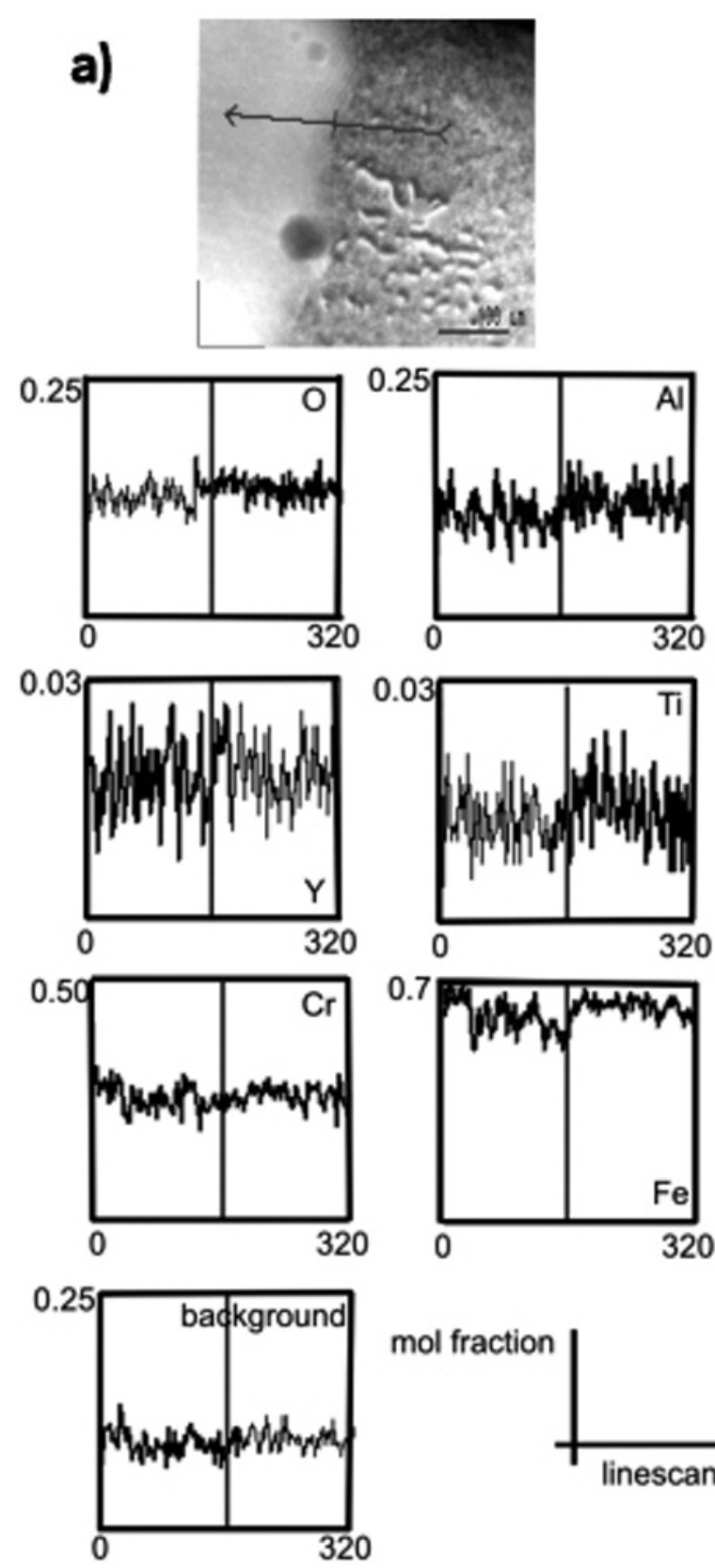

b)
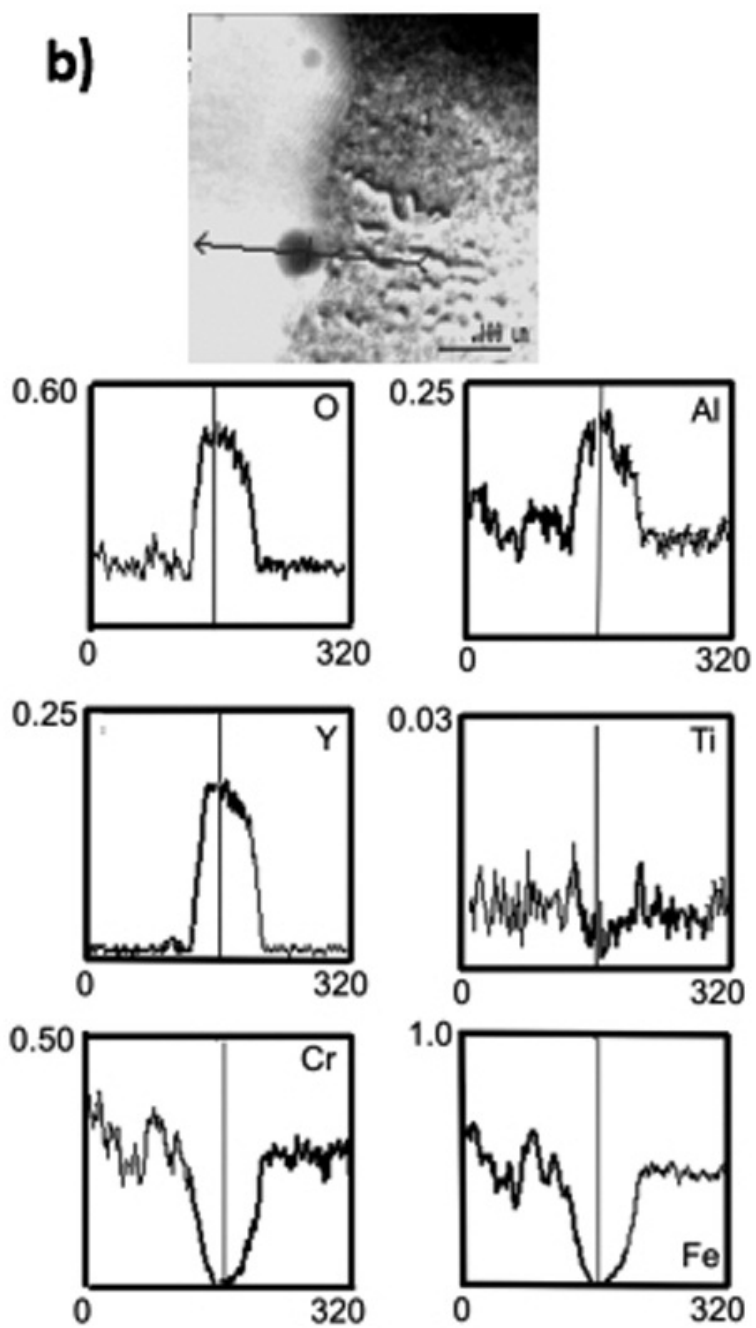

0.12

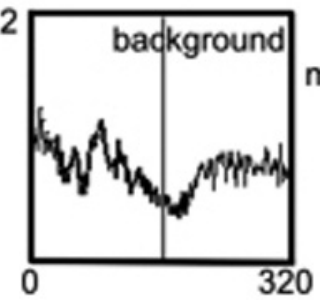

mol fraction

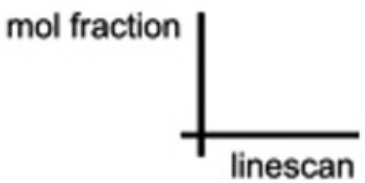

Figure 6. STEM - EDX microanalysis of the grain boundary. Linescan length of $320 \mathrm{~nm}$. (After ${ }^{[25]}$ ).

Figura 6. Microanálisis STEM-EDX de una frontera de grano. Línea de $320 \mathrm{~nm}$ (según ${ }^{[25]}$ ).

\section{INCREASED HOOP STRENGTH IN TUBES}

In pressurised tubes, the maximum principal creep stress demands peak strength in the hoop direction so the tubing exhibits substantially weaker creep resistance in the hoop direction when compared with that along the tube axis. To overcome this problem, a novel processing route developed at MSR Metall-Spezialrohr GmbH ${ }^{[22]}$ has been used. In this, the extruded tubes are flow formed in a process of three-rollers torsional extrusion, which leads to a varying reduction in wall thickness. Flow forming is a process of chipless manufacture, in which the material of the tube is subjected to compressive stress between a mandrel (located inside the tube) and three work-rollers located symmetrically around its circumference. Due to the proprietary design of the rollers, the tube not only extends but also twists, the total deformation being a combination of torsion and extrusion. Since the yttria particles are aligned along the extrusion direction, on extrusion, they tend to align along 


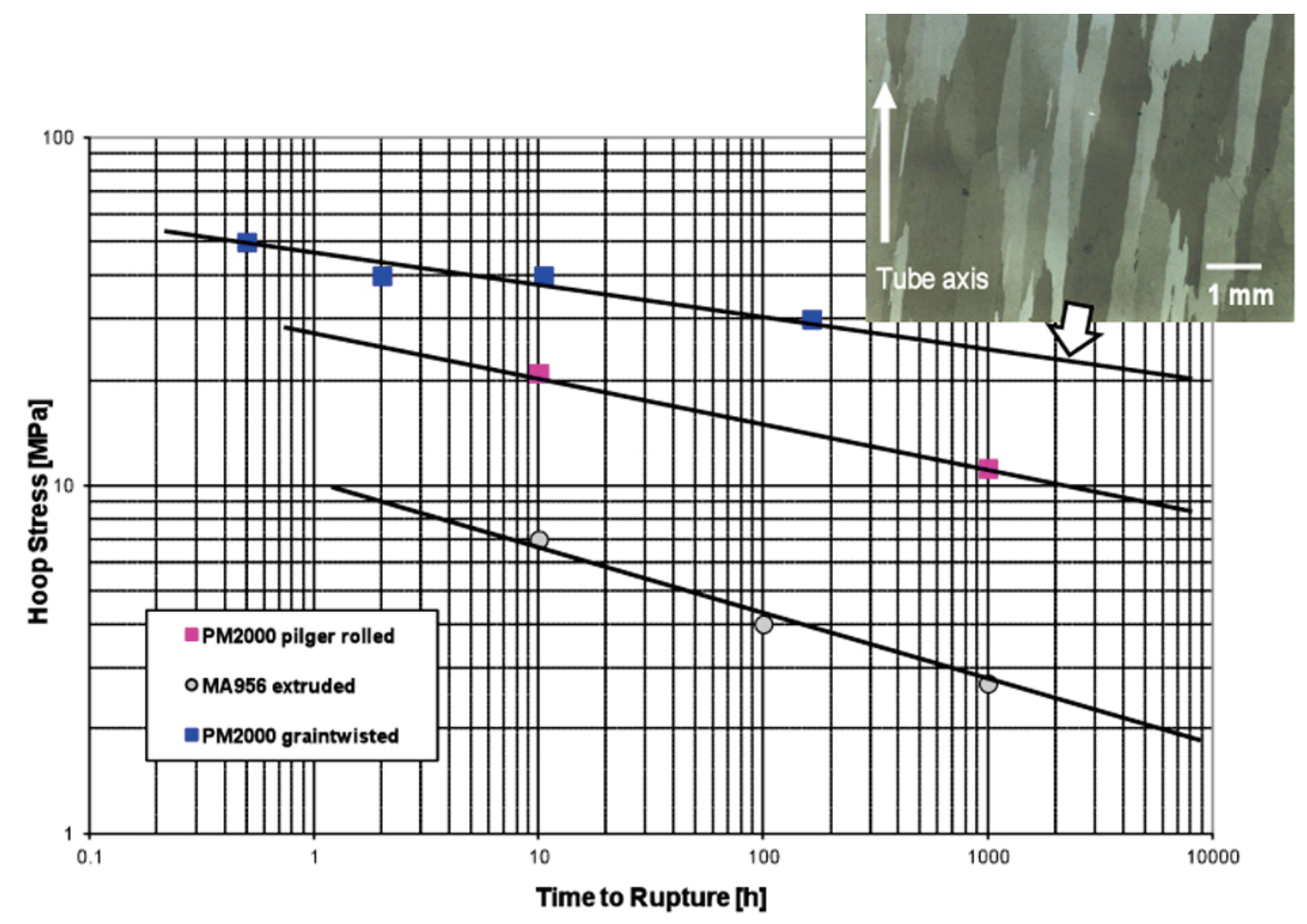

Figure 7. Creep strength in the hoop direction at $1100^{\circ} \mathrm{C}\left(\right.$ After $\left.{ }^{[27]}\right)$.

Figura 7. Resistencia a la fluencia en la dirección circunferencial a $1.100{ }^{\circ} \mathrm{C}$ (según [27]).

the elongation direction of the particles, which in this case is also the extrusion direction. The purpose of this torsional deformation is to cause these axially aligned particles to turn into helical arrangements in the hope that the material then recrystallizes into grains which twist along the extrusion axis and hence give better hoop strength. Assuming, therefore, flow forming processing with reduction in thickness above $75 \%$, the creep strength of flow formed material increase substantially with respect to extruded bar as it is shown in figure 7 . This figure shows the hoop creep strength, and can be concluded that with the flow forming technique the potential of ODS alloys can be exploited to a much higher percentage than with straight extrusion of tubes or pilger rolling (hot-rolling).

\section{STRAIN GRADIENT EFFECT}

So far, it has been shown that the flow forming processing technique can substantially improve creep strength in the hoop direction of ODS alloys. However, it is still uncertain the recrystallization mechanisms and how deformation can affect recrystallization.

The minimum recrystallization temperature $\left(T_{R}\right)$ is defined as that at which recrystallization is initiated within one hour of heat treatment. Values of this temperature measured at the inner and outer tube surfaces, for a variety of flow-forming reductions, are listed in table I.

Recrystallization initiates by the bowing of grain boundaries, a process which is difficult when the initial grain structure is so fine that the distance between grain boundary junctions is less than the size of a critical boundary perturbation ${ }^{[23]}$. This prevents the recrystallization of ODS alloys such as PM 2000 until very high temperatures are reached. With the sub-micrometer grain size of mechanically alloyed metals, the grain junctions themselves act as severe pinning lines for grain boundary bowing. A second factor is that the grain structure following mechanical alloying and consolidation of the powder is very uniform. Recrystallization should in these circumstances 
Table I. Minimum recrystallization temperatures $\left(T_{R}\right)$ as a function of level of deformation $\left(T_{\text {Rinn }}=\right.$ minimum recrystallisation temperature of inner surface; $T_{\text {Rout }}=$ minimum recrystallisation temperature of outer surface)

Tabla I. Temperatura mínima de recristalización $\left(T_{R}\right)$ en función de la reducción en área del tubo ( $T_{\text {Rinn }}=$ temperatura mínima de recristalización de la superficie interior; $T_{\text {Rout }}=$ temperatura mínima de recristalización de la superficie exterior)

\begin{tabular}{crc}
\hline$\%$ reduction-in-thickness & $\mathrm{T}_{\text {Rinn }} /{ }^{\circ} \mathbf{C}$ & $\mathrm{T}_{\text {Rout }} /{ }^{\circ} \mathbf{C}$ \\
\hline 0 & 1340 & 1290 \\
50 & 975 & 750 \\
75 & 1175 & 845 \\
90 & 1200 & 1180 \\
\hline
\end{tabular}

become easier if a non-uniformity is introduced, for example by introducing local distortions in the microstructure by heterogeneous deformation in the consolidated product. This is demonstrated in figure 8 , which shows that $T_{R}$ goes through a minimum as a function of the plastic strain. The strain distribution in the sample is expected to be most heterogeneous at intermediate strains leading to the minimum.

Therefore, there is no doubt that flow forming will modify recrystallization microstructure as it is shown in figure 9. This figure shows the through thickness microstructure for flow forming reductions of $50 \%, 75 \%$ and $90 \%$ reduction-inthickness.

In this sense, $50 \%$ reduction leads to a very fine recrystallized microstructure, i.e. high values of surface per unit volume $\left(\mathrm{S}_{\mathrm{V}}\right)$ of recrystallized grains, meanwhile coarse and elongated recrystallized grains are obtained for reduction in area above $75 \%$ (Fig. 10 a)). The grain aspect ratio (GAR), i.e. the ratio between sizes in longitudinal and transverse directions, is also strongly influence by flow forming process as it can be concluded from

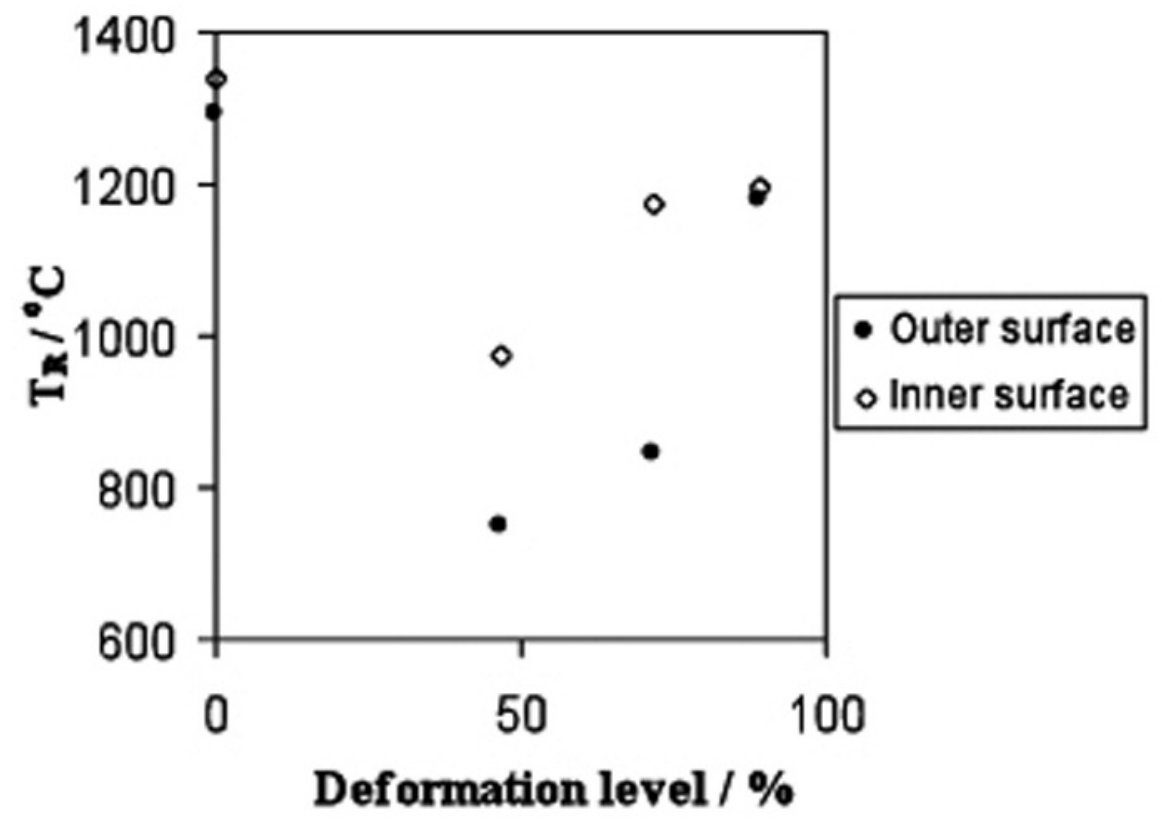

Figure 8. Evolution of TR as a function of deformation (reduction in thickness) of PM 2000 following flow-forming consolidation.

Figura 8. Evolución de TR en función del grado de deformación (reducción de espesor de pared de tubo) en PM 2000 por consolidación por flow-forming. 
GAR evolution with flow forming reductions shown in figure $10 \mathrm{~b}$ ). The highest the deformation is, the highest the GAR value is. These results might indicate that flow forming process induces a through thickness strain gradient and recrystallize grain size is strongly dependent on such gradient.

It is also clear the variation in recrystallized grain size through thickness in $50 \%$ and $75 \%$ flow forming reduction tubes, meanwhile homogeneous and coarser recrystallized grains are obtained in $90 \%$ flow forming reduction tube. This fact could be due to the throughthickness strain distribution due to flow forming process. During flow-forming, the surface of the tube is in contact with the rollers whereas the interior is in contact with a stationary mandrel. The torsional influence of the rollers does not therefore penetrate effectively through the thickness of the tube when the reduction is wall thickness is small. To summarize, the deformation is more uniform through the thickness of the tube for the larger reduction in wall thickness.

The fact that the overall deformation is more homogeneous as flow forming deformation increases is confirmed by the data presented in figure 11, which shows the evolution of the hardness across the wall thickness of the $75 \%$ and $90 \%$ reduction tubes. The hardness distribution into $90 \%$ reduction is clearly more homogeneous than that in $75 \%$ reduction-inthickness tube.

The crystallographic texture has also been measured as a function of depth in the deformed tube (Fig. 12). The outer surface of $75 \%$ reduction tube has a fairly strong fibre texture with axis $\mathrm{RD}=[100]$. By contrast, the centre of the tube has a weak almost random texture, whereas the inner surface shows a strong texture dominated by a rotated cube component $(\mathrm{TD}=[110] \mathrm{RD}=[001])$.

The texture results of $90 \%$ reduction tube are shown in figure 13. The three textures from the outside, centre and inside all show a maximum where $\mathrm{RD}=[100]$. Three ideal orientations dominate the texture: Rotated cube (101)[110], and $(1-11)[1-10]+(111)[1-10]$. The textures become stronger when moving from outer surface towards inner surface. Near the outer surface the texture is fibre-like (fibre axis $R D=[100]$ ). The fibretendency decreases towards the inside. There are similarities in the textures results of $75 \%$ and $90 \%$ reduction-in-thickness tubes: rotated cube component, fibre-like on outside, strong texture on inside. There are also differences: the $(1-11)[1-10]$ and (111)[1-10] components are not clearly observed in $75 \%$ reduction tube. Likewise, $90 \%$ reduction tube shows a steady increase in texture strength from outside to inside, whereas $75 \%$ reduction tube has a fairly weak texture in

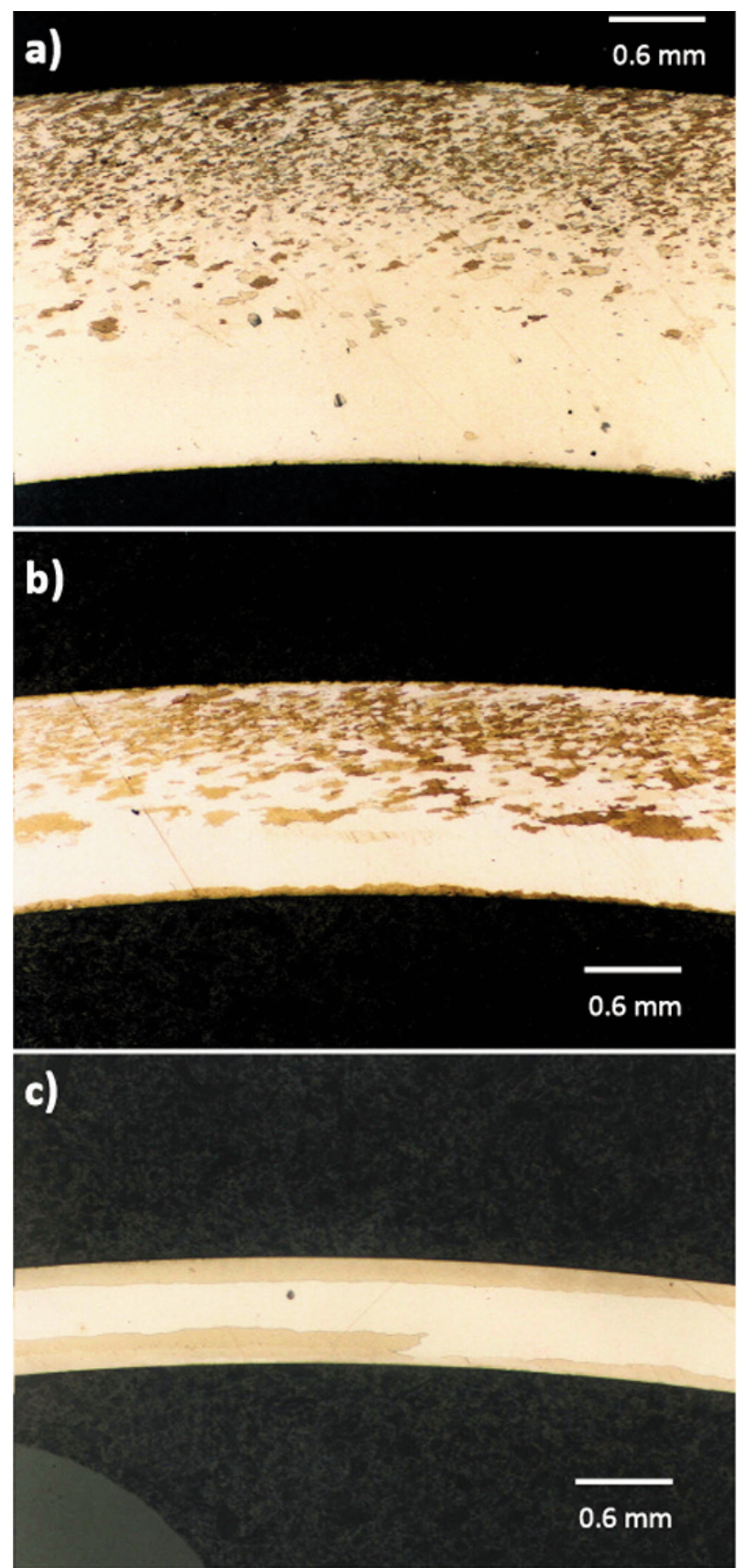

Figure 9. Transversal section of a) $50 \%$, b) $75 \%$ and c) $90 \%$ reduction in thickness tubes.

Figura 9. Sección transversal de a) $50 \%$, b) $75 \%$ y c) $90 \%$ de reducción en espesor de pared.

the centre. In general, it might be concluded that the texture is more homogeneous over the tube thickness for $90 \%$ reduction tube, which is consistent with the more homogeneous distribution of strain in $90 \%$ reduction tube shown in figure 11 . To summarize, the existence of a strain gradient through thickness after flow forming leads a change in texture that can promote the nucle- 

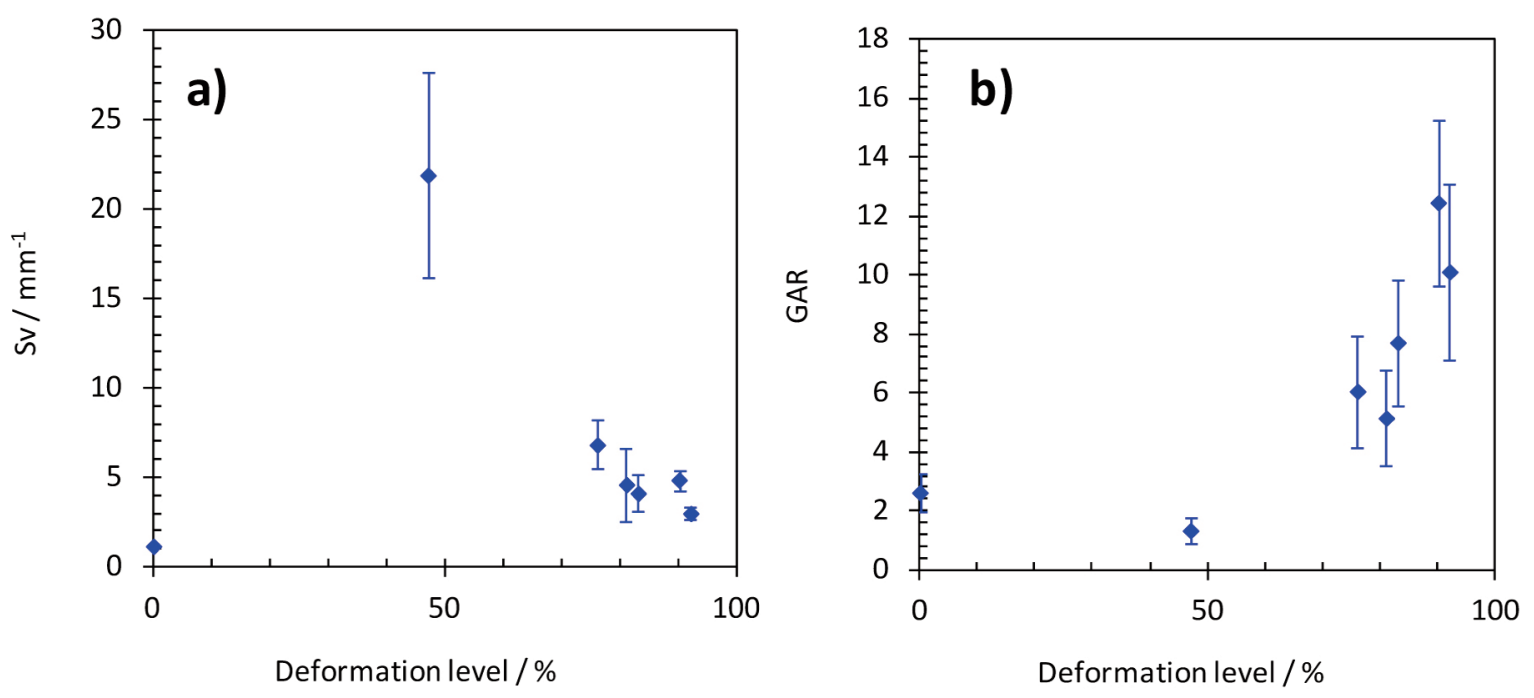

Figure 10. a) Sv and b) GAR evolution with thickness reduction in flow formed PM 2000 tubes.

Figura 10. Evolución de a) Sv y b) GAR con la reducción en espesor del tubo de PM 2000.

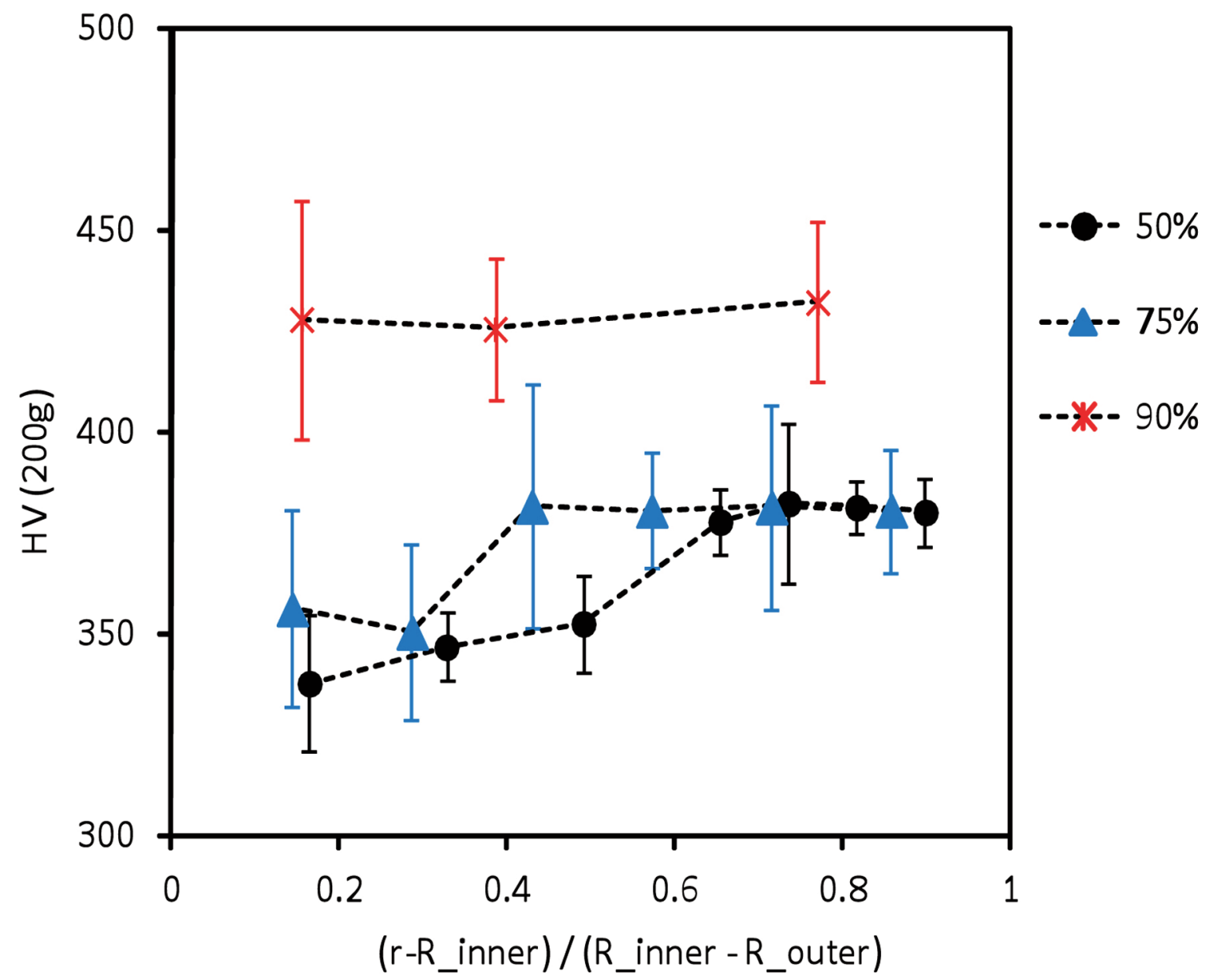

Figure 11. Comparison of strain gradient across the wall-thickness of the tube between $50 \%$ and $90 \%$ reduction-in-thickness tubes.

Figura 11. Comparación del gradiente de deformación a través del espesor de pared de un tubo con reducciones en área entre $50 \%$ y $90 \%$. 

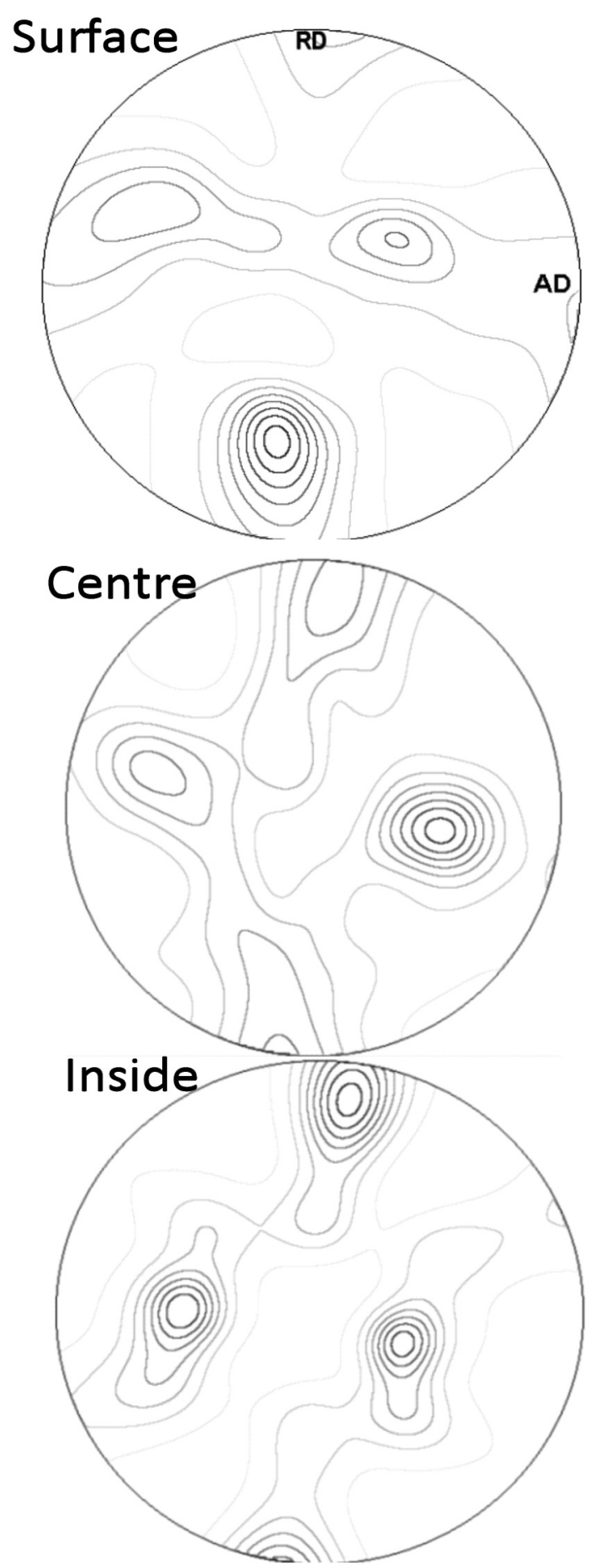

Figure 12. Texture at surface, centre, and inside of $75 \%$ reduction-in-thickness tube after flow forming.

Figura 12. Textura en superficie, centro y cara inferior de un tubo después de una reducción del $75 \%$ en espesor.

ation of recrystallization. However, the strain gradient is not the solely responsible for triggering
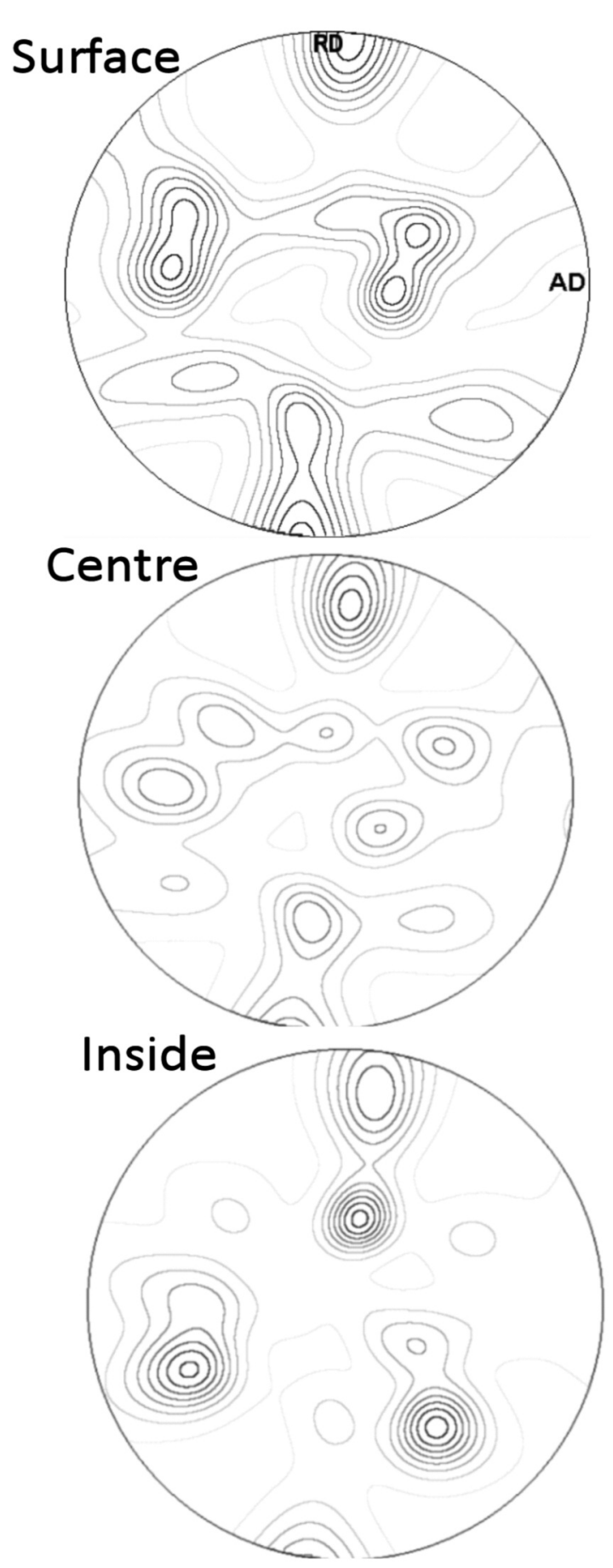

Figure 13. Texture at surface, centre, and inside of $90 \%$ reduction-in-thickness tube after flow forming.

Figura 13. Textura en superficie, centro y cara inferior de un tubo después de una reducción del $90 \%$ en espesor

recrystallization, but residual stresses can also play a role as it is shown in the following section. 


\section{EFFECT OF RESIDUAL STRESSES}

The role of residual stresses is analyzed by combing simple deformation tests such as Brinell indentation test and finite element modeling. In this sense, a systematic study of the early stages of recrystallization as a function of annealing temperature and deformation was carried out.

Table II lists the $T_{R}$ temperatures after isochronal $(3 \mathrm{~h})$ heat treatments at different annealing temperatures. It could be concluded that deformation boost recrystallization, i.e. the higher deformation the lower $T_{R}$. The recrystallization temperature in absence of deformation was determined at $1330^{\circ} \mathrm{C}$. The first observable result is seen in the case of $4.9 \mathrm{kN}$ at $1320^{\circ} \mathrm{C}$. Deformation of $49 \mathrm{kN}$ causes a drop to $\mathrm{T}_{\mathrm{R}}$ down to $1150^{\circ} \mathrm{C}$. Figure 14 illustrates the effect of increasing deformations on subsequent recrystallization of PM 2000. It is evident the effect of the deformation magnitude on the recrystallization, since the bigger the indentation load, the more extended the volume of recrystallized material and finer the recrystallized grain size.

These results are consistent with the ones reported by Nutting ${ }^{[24]}$ and Capdevila et al. ${ }^{[25]}$. Nutting studied the recrystallization process in a $60 \%$ cold worked sheet which was slightly deformed by bending, and claimed that recrystallization was triggered in places subjected to residual compressive stresses ${ }^{[24]}$. Capdevila reported a two-fold effect on the recrystallization behavior of specimens subjected to different bending angles: As cold deformation increases it was noted a decrease in the recrystallization temperature and an increase in the density of recrystallization nuclei disregarding of the stress direction ${ }^{[25]}$.

Toda et al. ${ }^{[26]}$ reported a calculation of residual stresses in Brinell indented sample by means of finite

Table II. $T_{R}$ values vs. Brinell load after $3 \mathrm{~h}$ isochronal heat treatments

Tabla II. Valores de $T_{R}$ frente a cargas del ensayo Brinell después de $3 \mathrm{~h}$ de tratamiento isócrono

\begin{tabular}{cc}
\hline Brinell test loads $(\mathbf{k N})$ & $\mathbf{T}_{\mathbf{R}}\left({ }^{\circ} \mathbf{C}\right)$ \\
\hline 49.0 & 1150 \\
29.4 & 1210 \\
19.6 & 1250 \\
4.9 & 1320 \\
0 & 1330 \\
\hline
\end{tabular}
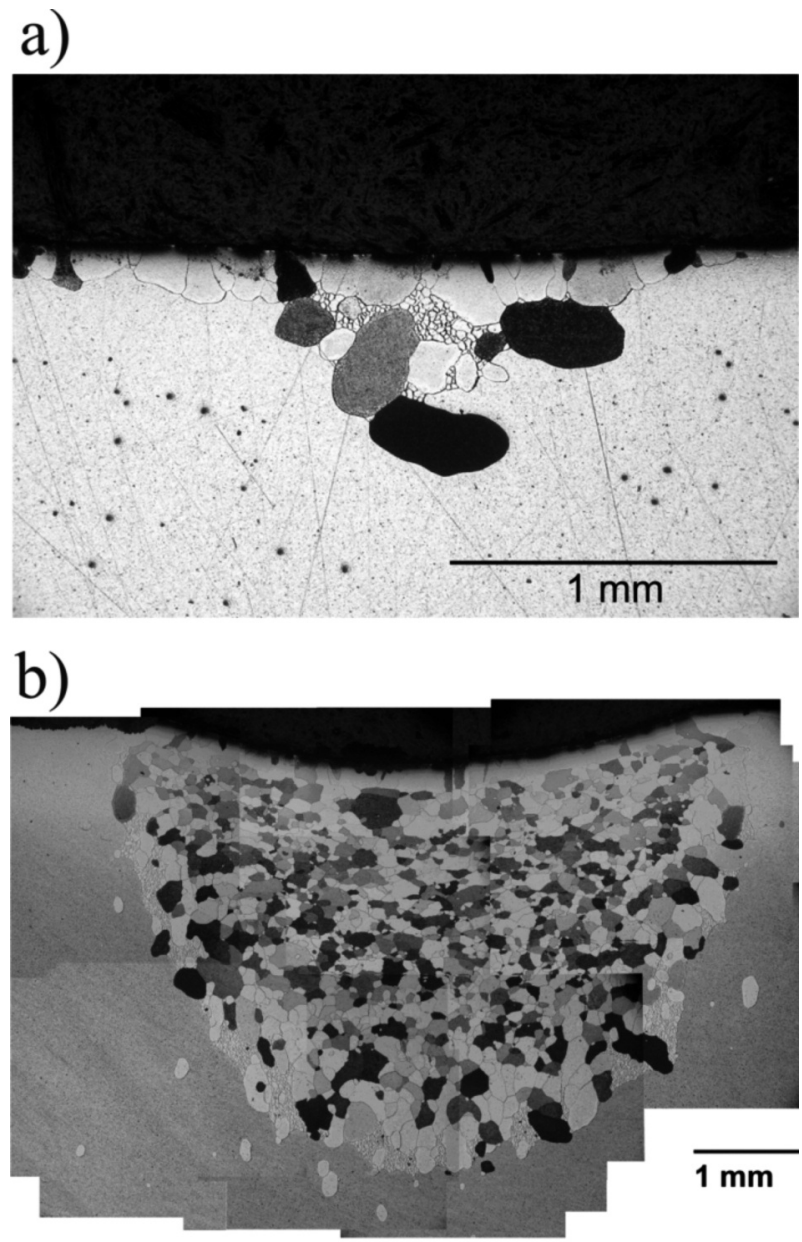

Figure 14. Recrystallized microstructure of deformed area after annealing at $1350^{\circ} \mathrm{C}$ for $3 \mathrm{~h}$ : a) $4.9 \mathrm{kN}$ and b) $49 \mathrm{kN}$. Transverse section to extrusion direction.

Figura 14. Microestructura de recristalización de un área deformada después de un recoido a $1.350^{\circ} \mathrm{C}$ durante $3 \mathrm{~h}$ : a) carga de $4.9 \mathrm{kN}, y$ b) carga de 49 kN. Sección transversal a la dirección de extrusión.

element modeling. Figure 15 shows a comparison between a shear residual stress $\left(\sigma_{\mathrm{xy}}\right)$ map reported by Toda et al, and the early stages of recrystallization in a deformed and subsequently heat treated at $1150^{\circ} \mathrm{C} / 3 \mathrm{~h}$ sample. It is clearly observed in this figure that the recrystallized zones (Fig, 15 b)) match with those where $\sigma_{x y}$ presents the highest values (Fig. 15 a)). This illustrates the role of shear stresses on recrystallization of Fe-base mechanically alloyed steels. This is consistent with the idea described by Hutchinson and Wynne ${ }^{[27]}$ where it is described that boundary movement is accompanied by shearing of the volume through which a boundary moves. While any high angle boundary may be formally described by a dislocation arrangement, it is not so evident 
a)

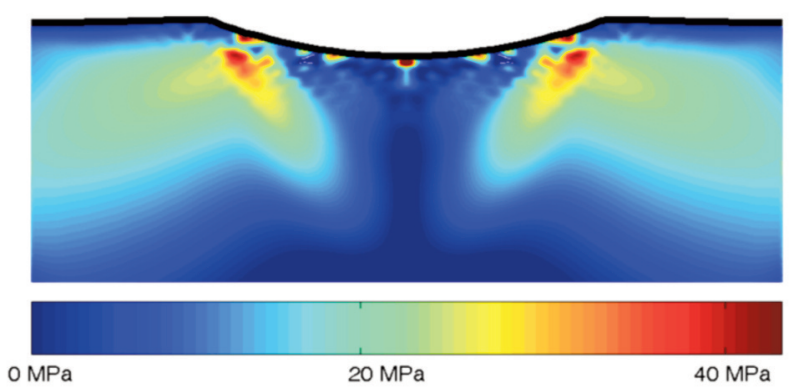

b)

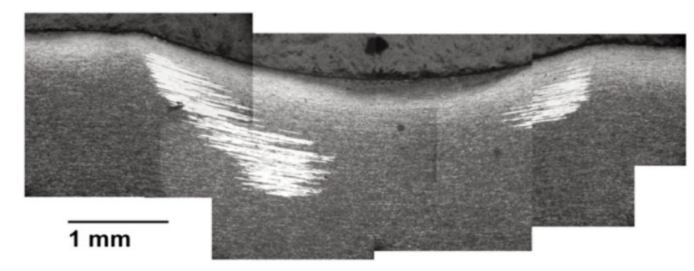

c)
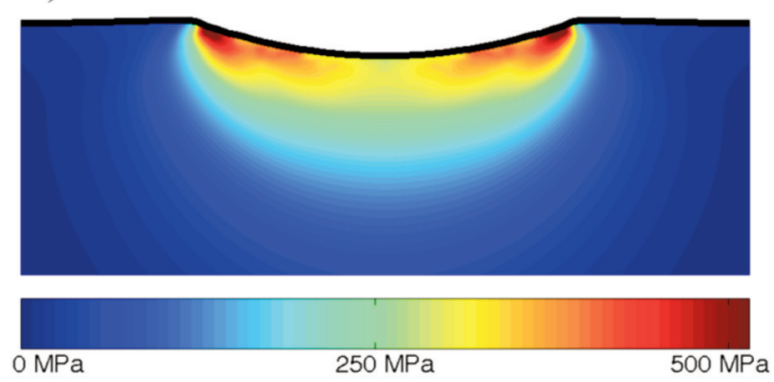

Figure 15. a) $\sigma_{x y}$ map at $1150{ }^{\circ} \mathrm{C}$ after $49 \mathrm{kN}$ load, b) recrystallization microstructure (in white) after $49 \mathrm{kN}$ load and subsequent annealing at $1150^{\circ} \mathrm{C}$ for $3 \mathrm{~h}$, and c) strain energy density map for $49 \mathrm{kN}$.

Figura 15. a) mapa de $\sigma_{x y}$ a $1.150^{\circ} \mathrm{C}$ después de una carga de $49 \mathrm{kN}, \mathrm{b})$ microestructura de recristalización (en blanco) después de una carga de $49 \mathrm{kN}$ y subsiguiente recristalización a $1.150^{\circ} \mathrm{C}$ durante $3 \mathrm{~h}$, y c) mapa de energía de deformación para una carga de 49 kN.

which dislocations are actually involved, and how to resolve the stress that drives them. In this case, it may be easier to think of structural units and coordinated jumps of atoms across the boundary providing the mechanism for migration. Which ever view point is adopted, it is important to remember that energy has to be supplied to provide that which is being dissipated during the boundary migration. This can only come from work done by the component of force acting parallel to the boundary and so shearing must always accompany migration when this is stress-driven, whatever the misorientation of the boundary. Since each element of grain boundary is an invariant plane, the only possible work is by translation parallel to the boundary or, in other words, by shearing the volume as the boundary passes through it. In this case, the significant stress component will be a shear stress parallel to the boundary.

The maximum possible driving force in this case is then equal to the work done per unit volume $\gamma \sigma_{\mathrm{xz}}$ where $\gamma$ is the shear strain accomplished, which depend on the misorientation and structure of the boundary (Fig. 15 c)).

\section{CONCLUSIONS}

- Flow forming is a powerful processing route that ensures a significant improvement of creep strength in the hoop direction in PM 2000 ODS alloy tubing by means of generating a coarse grain recrystallized microstructure following a helicoidal pattern.

- The influence of cold deformation on the recrystallization of mechanically alloyed PM 2000, has been studied. Tubes with different levels of deformation due to flow-forming have been studied. As the reduction in area increases, a more homogeneous sub-micron microstructure and strain gradient across the wall thickness of the tube is observed.

- The triggering of recrystallization in a cold deformed sample of PM 2000 is a consequence of two additive factors such as the existence of residual stresses and the increase of strain energy. The presence of residual shear stresses at the moment of recrystallization boosts the grain boundary movement and hence reduces the recrystallization temperature. The latter is responsible of the through thickness crystallographic texture changes that can boost the nucleation of recrystallization.

- The results presented in this paper from hardness, microstructure and crystallographic texture are all consistent with the broad idea that anything which introduces heterogeneity into the microstructure, stimulates the nucleation of recrystallization, giving a fine-grained microstructure.

\section{Acknowledgements}

G. Pimentel acknowledges the Spanish Ministerio de Ciencia e Innovación for financial support in the form of PhD research grant (FPI). This work was 
partly supported by the Spanish Ministerio de Educación y Ciencia in the Plan Nacional 2006-2011 Framework projects ENE2006-15170-C02 and ENE2009-13766-C04.

\section{REFERENCES}

[1] D. J. Gooch: in Proc. 5th International Charles Parsons Turbine Conference, Institute of Materials, London, England, 2000, p. 201.

[2] T. Leino, J. Kärki, P. Vainikka, M. Orjala, L. Díez, C. Cortés, H. van Putten, D. Bosma, A. Tortosa-Masia, A. Otter, F. Klemm, S. Mabbutt, N. Simms, J. Oakey, E. Kakaras, N. Koukouzas, P. Grammelis, D. Chua, I. Rampidis and A. Anttila, Development of advanced monitoring methods to improve boiler availability and performance, Report EUR22994EN, DirectorateGeneral for Research, European Union, Luxembourg, 2008, p. 4.

[3] D. Sporer and K. Lempenauer, in Proc. 13th International Plansee Seminar, Bildstein-Eck, Reutte, Austria,1993, p. 796.

[4] F. Starr, A. R. White and B. Kazimierza, in Proc. Materials Advanced Power Engineering, D. Coutsouradis, E. Bachelet, R. Brnetaud, P. Esslinger, J. Ewald, I. Kvernes, Y. Lindblom, D. B. Meadowcroft, V. Regis, R.B. Scarlin, K. Schneider and R. Singer (eds), Kluwer Academic Publishers, The Netherlands, 1994, p. 1393.

[5] F. G. Wilson, B. R. Knott and C. D. Desforges, Metall. Trans., 9A (1978) 275-287.

[6] M. M. Baloch, PhD Thesis, University of Cambridge, Cambridge, 1989, p. 91.

[7] D. M. Jaeger and A. R. Jones, in: Proc. Materials Advanced Power Engineering, D. Coutsouradis, E. Bachelet, R. Brnetaud, P. Esslinger, J. Ewald, I. Kvernes, Y. Lindblom, D. B. Meadowcroft, V. Regis, R.B. Scarlin, K. Schneider, R. Singer (eds), Kluwer Academic Publishers, The Netherlands, 1994, p.1507.

[8] D. M. Jaeger and A. R. Jones, in: Proc. Materials Advanced Power Engineering, D. Coutsouradis, E. Bachelet, R. Brnetaud, P. Esslinger, J. Ewald, I. Kvernes, Y. Lindblom, D. B. Meadowcroft, V. Regis, R.B. Scarlin, K. Schneider and R. Singer (eds), Kluwer Academic Publishers, The Netherlands, 1994, p. 1515.

[9] T. S. Chou, H. K. D. H. Bhadeshia, G. McColvin and I. C. Elliot, in Proc. 2nd
International Conference on Structural Applications of Mechanical Alloying, ASM, Ohio, 1993, p. 77.

[10] T. S. Chou and H. K. D. H. Bhadeshia, Metall. Trans., 24A (1993) 773-779.

[11] T. S. Chou and H. K. D. H. Bhadeshia, Mater. Sci. Technol., 9 (1993) 890-897.

[12] J.L. Gonzalez-Carrasco, J. Chao, C. Capdevila, J.A. Jimenez, V. Amigo and M.D. Salvador, Mat. Sci. Eng. A, 471 (2007) 120-126.

[13] J. Chao, C. Capdevila and J.L. GonzálezCarrasco, Mat. Sci. Eng. A, 515 (2009) 190. 195.

[14] M. Klimiankou, R. Lindau, A. Moslang and J. Schroder, Powder Metall., 48 (2005) 277-287.

[15] M. Klimiankou, R. Lindau and A. Möslang, Journal of Crystal Growth, 249 (2003) 381 388.

[16] J. S. Benjamin and P. S. Gilman, Metals Handbook, 9th edn., Vol. 7, ASM International, Ohio, 1983, p. 722.

[17] G. H. Gessinger, Powder Metallurgy of Superalloys, Butterworth, London, England, 1984, p. 356.

[18] G. A. J. Hack, Powder Metall., 27 (1984) 73 79.

[19] C. Capdevila, Y. L. Chen, N. C. K. Lassen, A. R. Jones and H. Bhadeshia, Mater. Sci. Technol., 17( 2001) 693-699.

[20] C. Capdevila, Y. L. Chen, A. R. Jones and H. Bhadeshia, ISI J. Int., 43 (2003) 777-783.

[21] C. C. Montes and H. Bhadeshia, Adv. Eng. Mater., 5 (2003) 232-241.

[22] U. Miller, P. Brondsted, A.R. Jones, A. Fleming, H. Jelenak and H.K.D.H. Bhadeshia, Development of Torsional Grain Structures to Improve Biaxial Creep Performance of Fe-based ODS Alloy Tubing for Biomass Power Plant (Graintwist), BRITE-EURAM III, BE 97-4949, European Union, Brussels, 2002, p. 148.

[23] H.K.D.H. Bhadeshia, Mat. Sci. Eng., A 223 (1997) 64-77.

[24] J. Nutting, S. Ubhi and T.A. Hughes., in Proc. Int. Conf. on Oxide Dispersion Strengthened Superalloys by Mechanical Alloying, J.S. Benjamin (Ed), IncoMAP, 1981, p. 33.

[25] C. Capdevila and H.K.D.H. Bhadeshia, Adv. Eng. Mater., 3 (2001) 647-656.

[26] I. Toda-Caraballo, J. Chao, L. E. Lindgren and C. Capdevila, Scr. Mater., 62 (2010) 41-44.

[27] B. Hutchinson and B. Wynne, Mater. Sci. Forum, 550 (2007) 149-157. 